Nidhomul Haq: Jurnal Manajemen Pendidikan Islam E-ISSN: 2503-1481

Accredited Ristekdikti: 28/E/KPT/2019

pp: $27-40$

DOI: https://doi.org/10.31538/ndh.v6i1.899

http://e-journal.ikhac.ac.id/index.php/nidhomulhaq

\title{
THE INFLUENCE OF ORGANIZATIONAL CULTURE AND WORK MOTIVATION ON TEACHER PERFORMANCE AT THE INTERNATIONAL STANDARD SCHOOL, AMANATUL UMMAH MOJOKERTO
}

Siti Rofifah1), Akhmad Sirojuddin2), Muhammad Anas Ma`arif3), Muhammad Mujtaba Mitra Zuana4), ${ }^{1-5}$ Fakultas Tarbiyah, Institut Pesantren Kh. Abdul Chalim Pacet Mojokerto, Indonesia Email: rofifahfachraa05@gmail.com

\begin{abstract}
Organizational Culture in a school and Institution is highly reflects values and norms which is being the vision and mission of the institution in achieving its goals. The suitable culture in its application will have a positive impact in work motivation to improve teachers' performance better. The good performances of Educators and education staffs will make the achievement results in the organization increase. This analysis used the independent variable of culture organization and work motivation, and independent variable is teacher performance. As for the sample in this study were the formal and informal teachers of MBI. In this study, the sample collection technique of researcher used probability sampling in simple random sampling, and the data collection technique use questionnaire which was distributed directly to 60 respondents. The result of this study shows that organizational culture (X1) and work motivation (X2) has a positive and significant effect on teacher performance $(\mathrm{Y})$ either particially or simultaneously. In thin study there is an effect between $\mathrm{X} 1$ and $\mathrm{Y}$ partially as seen from the $\mathrm{t}$-test result that the $\mathrm{t}$ research is $2.655>\mathrm{t}$ table is 2.00247 , for the effects is $54,5 \%$. And there is an effect between $\mathrm{X} 2$ and Y partially as seen from the $\mathrm{t}$-test result that the $\mathrm{t}$ research is $2,181>\mathrm{t}$ tabel 2,00247 , for the effects is $44.7 \%$. And find the result of the calculation of the effect simultaneously that is $96.8 \%$.
\end{abstract}

Keywords: Organizational Culture, Work Motivation, Teacher Performance, International Standars School

\begin{abstract}
Abstrak
Budaya Organisasi di Sekolah dan Lembaga sangat mencerminkan nilai dan norma yang menjadi visi dan misi lembaga dalam mencapai tujuannya. Budaya yang sesuai dalam penerapannya akan berdampak positif pada motivasi kerja untuk. meningkatkan kinerja guru menjadi lebih baik. Kinerja Pendidik. dan tenaga kependidikan yang baik akan membuat hasil prestasi dalam organisasi semakin meningkat. Analisis ini menggunakan variabel bebas budaya organisasi dan motivasi kerja, sedangkan variabel bebasnya adalah kinerja guru. Adapun sampel dalam penelitian ini adalah guru formal dan informal MBI. Dalam penelitian ini teknik, pengambilan sampel peneliti menggunakan probability sampling dengan cara simple random sampling, dan teknik. pengumpulan datanya menggunakan kuesioner yang dibagikan langsung kepada 60 responden. Hasil penelitian menunjukean bahwa budaya organisasi $(X 1)$ dan motivasi kerja (X2) berpengarub positif dan signifikan terhadap kinerja guru (Y) baik secara parsial maupun simultan. Pada penelitian tipis terdapat pengaruh antara X1 dan Y secara parsial dilihat dari hasil uji t bahwa t penelitian sebesar 2.655> t tabel 2.00247, untuk pengaruh sebesar 54,5\%. Dan terdapat pengaruh antara X2 dan Y secara parsial terlibat dari hasil uji t bahwa t penelitian sebesar 2,181> $t$ tabel 2,00247, untuk pengaruh sebesar 44,7\%. Dan mendapatkan hasil perbitungan pengarub secara simultan yaitu $96,8 \%$.
\end{abstract}

Keywords: Budaya Organisasi, Motivasi Kerja, Kinerja Guru, Sekolah Bertaraf International.

\section{INTRODUCTION}

Schools are educational institutions that have an obligation to serve public education which aims to provide intelligence for the nation's successors
(students)(M. Abdullah, 2019; Berglund, 2019). Therefore, the role that schools have is very important and used as a means of carrying out the need for an education. In implementing education in schools, teachers 
are people who are needed during education(Ab Halim Tamuri et al., 2013; Fajriana \& Aliyah, 2019; Ridwan, 2018).

The teacher is the most important part in implementing education. The success of the teaching and learning process and the quality of education are largely influenced by teachers (educators)(Baker \& Reyes, 2020; Chalim et al., 2020; Nadolny, 2011). Therefore, attention to teachers will be a priority in order to always provide increased educational outcomes. In Law (UUD) Number 20, 2003, which contains an explanation of the National Education System which explains that educators (teachers) are professional staff and are assigned to plan, implement, assess and carry out guidance and training. Especially for educators in higher education, they are required to do research and also serve the community.

International Standard Madrasah (MBI) Amanatul Ummah (AU) is part of the excellent Amanatul Ummah institution, and has an " $\mathrm{A}$ " accreditation located in Pacet Mojokerto, every year it always passes $100 \%$ in the UN and almost all students or $98 \%$ of they continue their education to State Universities. In the new Academic Year 2014-2015, MBI AU opens 10 classes for new student registration. The MBI facilities and infrastructure are well processed and presented, providing a curriculum that can summarize the National
Curriculum, the International Curriculum, and the Al-Azhar curriculum (Cairo-Egypt). The MBI AU has also become the object of comparative studies for schools / madrasahs from almost all over Indonesia.

MBI AU Pacet Mojokerto has an excellent organizational culture to build great character and discipline for students and educators. In admitting new teachers, MBI Amanatul Ummah has standardized teachers, that is, they must have completed at least a Bachelor's degree (S-1) education. There is also a culture that exists, namely regarding the provision of monitoring and evaluation, in MBI there are meetings between leaders and teachers that are held, namely weekly, monthly and also annual meetings.

In an effort to improve the performance of teachers, organizational culture in institutions or madrasah has a very important role. The role of culture is used as a tool in determining the direction and goals of the organization, directing what should be done and left behind and also providing the same understanding to teachers (educators) about how the organization should be and also how educators (teachers) behave and motivate. work given in an effort to improve teacher performance in it.

Work motivation at MBI is well provided by both the leadership and the institution. In order to continue to improve 
the performance of teachers in these madrasas. Apart from demanding obligations, there are rights and welfare of teachers which are also given or facilitated. Namely in the case of honorary awards, in which MBI has 3 levels (grade) of teachers, namely: grade A, B and C and also provides facilities called BMI (Baitul Maal wal Isti'arah), namely interest-free and collateral-free loan facilities, and there are also awards. As well as related to performance, such as in terms of discipline, from when they enter to return from school, they are obliged to perform absences, namely using a smart card which is one of the systems used by the institution, and this also applies to educators or teachers who teach at therein.

The definition of performance according to Suntoro is the result of the performance achieved by individuals and groups of people who are in the madrasah (institution), this achievement must be in accordance with the rules and norms that exist within the madrasah as well as full responsibility for achieving the goals of the madrasah (Abd Hamid et al., 2012; Darma \& Supriyanto, 2017; Felicen et al., 2014). Good or bad performance of educators is sometimes influenced by internal factors as well as external factors, and must be a concern for madrasah management (Alkrdem \& Alqahtani, 2016; Hassi, 2012). Performance is a description of the level of achievement of the implementation of an activity program or policy so that the goals, objectives, vision and mission of the organization are realized through the strategic planning of an organization(Jones \& Rao, 2008; Marquardt, 2011). Performance can be known and measured if an individual or group of education personnel already has criteria or benchmarks for success standards set by the organization(Hallinger \& Hammad, 2019). And in order for the plan to be successful, the principal can conduct monthly evaluations such as meetings, which aim to find out the report on the performance of the existing education personnel(Mesiono, 2019; Siahaan et al., 2020).

Talking about performance does not escape from Human Resources (HR) as the perpetrator. HR here is defined as a teacher in a school (Mathis \& Jackson, 2011, 2011). Schools really need a teacher who is able to provide good quality, loyalty and is able to improve their performance in order to achieve school goals (Belcourt \& McBey, 2013; Young, 2009). In a study conducted by Marwan, it provides conclusions from the results of research which indicate that performance is directly influenced by leadership behavior, organizational culture, achievement motivation and job satisfaction. So according to this study, organizational culture can also affect teacher performance. 
In connection with the realization of school goals, this cannot be separated from the performance of the teachers who are in the school. Teacher performance is basically focused on teacher behavior in their work(Chhapra et al., 2018).

Organizational culture also has an influence on teacher performance, because culture is a habit that is embedded in teachers (M. L. Abdullah \& Syahri, 2019; Alam, 2018). For example, a culture of discipline embedded in schools that requires teachers not to arrive late. If this culture has been implemented, the work that is accountable to teachers will be carried out effectively and efficiently(Warti'ah, 2020). However, in carrying out the culture of the institution, it is expected that it is always carried out by teachers and must also be motivated by the leaders. And so it is with motivation, if motivation continues to be given, the teacher's performance will be maximized in carrying out their duties(Brandmiller et al., 2020).

Motivation is a very important subject for managers, because the existence of a motivation can provide an increase in the productivity of members while working. There are three kinds of motivation that can be known, first, motivation can provide a description of strength (energy) so that it can behave properly when carrying out activities. Second, a movement has a goal of orientation from motivation to achieve the goals of the organization. Third, it can provide motivation in doing a job. The strength of a spirit will be a very strong impetus for him (internal factors) and his work environment. Another cause is the factor of cultural values in an institution so that it can give a boost to high performance (work performance)(Hagger \& Chatzisarantis, 2012).

Job satisfaction is related to someone's hope for a prosperous life. Satisfaction of performance for teachers will have an impact on discipline, achievement and the quality of their work. For teachers who feel satisfaction from work results, it can also have a positive influence in improving the quality of an education(Chen \& Chen, 2014). Likewise, if the job satisfaction of teachers is low, it will also have a negative impact on the development of the quality of education. For example, teachers who do not carry out their obligations, do not use lesson planning, and also always complain are signs of a low satisfaction for teachers. Therefore, organizational culture and motivation have a very big impact on teacher performance satisfaction(Amaliah et al., 2015).

Based on the results of research conducted by Rahayu entitled "The relationship between organizational culture and teacher performance in private elementary schools in Koto Tengah district, Padang. Has an indicator of the quality of 
work results and the time used, has a high category with a value of $81.41 \%$. The organizational culture of teachers in Private Elementary Schools (SDS), Koto Tengah District, Padang, and was stated to be sufficient with a value of $78.75 \%$. Therefore it can be concluded that there is an influence of organizational culture on teacher performance(Ishan, 2018).

Then the second is produced by a researcher named Madyo Ekosusilo, who provides research conclusions and shows that organizational culture in schools, the behavior of a leader, pedagogical abilities, enthusiasm, and performance simultaneously have a positive and significant effect on the satisfaction of teachers' performance results. value $65,827 \%$. Based on this description, it can be concluded that human resource management needs to pay attention to organizational culture, compensation and performance motivation because it will affect teacher performance, either directly or indirectly, and will also affect the quality and productivity of the institution or madrasah(Ekosusilo \& Soepardjo, 2014).

Based on the background of the problems described above, the researcher is interested in conducting a study with the title "The Influence of Organizational Culture and Work Motivation on Teacher Performance at the International Standard
Madrasah (MBI) Amanatul Ummah Pacet Mojokerto".

\section{METHOD}

The design in this study is a design for the research procedures to be carried out and is also used in obtaining answers to the research statements that have been formulated. In the implementation of this study using analysis techniques from quantitative data and has the aim to test the hypothesis between the hypothesized variables and explain the causal influence between the variables through testing the hypothesis. The purpose of hypothesis testing is to determine the probability that the hypothesis is supported by empirical facts or data(Muri, 2017; Sugiyono, 2014).

The implementation of this research is located at MBI Nurul Ummah Pacet Mojokerto, Jalan Raya Tirtowening No. 2, Kembangbelor village, Pacet sub-district, Mojokerto district, East Java province, postal code 61374. Researchers consider in determining the research location based on the following aspects: there are teacher performance that is not too optimal, skills and efforts are still needed for optimal organizational culture and motivation ongoing work to improve teacher performance at MBI.

\section{RESULT AND DISCUSSION}

According to Sugiyono, what is meant by sample in a quantitative study is 
part of the number and characteristics of the population. The determination of the number of samples from a certain population developed from Isaac and Michael for the error rate, namely, 1\%, 5\% and $10 \%$. The population used by the researchers in this study were the teachers at the International Standard Madrasah (MBI) Amanatul Ummah Pacet Mojokerto.

In the following, the researcher can present a discussion description of the research results based on each variable and to answer the research hypothesis which can be described below:

\section{The Influence of Organizational Culture on Educator Performance}

Based on the results of the analysis (t-test), it can be seen that there is a positive and also significant influence between organizational culture on teacher performance at MBI AU Pacet Mojokerto, so that the results of the calculation are $54.5 \%$, with a research $\mathrm{t}$ of $2.655 .>\mathrm{t}$ table of 2.00247. So based on the results of the calculation of this significant figure obtained from testing the questionnaire on variable X1 (organizational culture) against $\mathrm{Y}$ (teacher performance) using SPSS version 25.

Organizational culture is the total values, norms, beliefs that are shared and upheld by members of the organization, so that culture provides a pattern and direction to the members of the organization. Which is related to this that organizational culture has many indicators that researchers have tested on respondents (research samples), including individual initiative, support for management, direction, communication patterns, and commitment and sincerity.

The organizational culture that exists and has been implemented or implemented by the MBI Amanatul Ummah Pacet Mojokerto educational institution is very good. Because the leaders or principals at MBI are called coordinators, have implemented a culture of mentoring, embracing each other, and continuously (intensely) in providing encouragement and support to teachers. In MBI, teachers are encouraged to have initiative and think creatively at work, and they are also given the freedom to express opinions regarding things that can be done in order to continue to improve the progress of the institution (madrasah) and increase the quantity and quality of student graduates (output) resulting from.

Then the management support at MBI is very good for teachers. The majority of teaching teachers at MBI AU Pacet are undergraduate education in accordance with their field of expertise and the standardization of teacher admission is required to have completed Bachelor. Some teachers have received a master's degree either in the discipline they teach or in related disciplines, which is useful for 
increasing the insight and professionalism of the teachers. because in MBI, teachers are supported by both leaders and institutions to continue their education. The AU Pacet MBI teachers are also very active in participating in existing activities, such as training and seminars which are very useful in the teaching and learning process. Apart from that, most of the MBI AU Pacet teachers can also take advantage of advances in technology in order to increase the effectiveness and efficiency of teaching and learning activities in schools and can also be competently professional.

In terms of direction as well as communication patterns, teachers can get motivation directly from the leadership because the MBI School is not limited by a formal hierarchy of authority between the leadership and the teachers, thus creating excellent communication links. And there are also organizational cultures in the MBI School, including: conducting regular weekly meetings led directly by the leader (coordinator) with the teachers. Which is done every Wednesday night (Thursday night) every week. In addition, the teachers also conduct monthly meetings or evaluations which are chaired by the Deputy Coordinator in each field. In MBI, there are several Wakoor namely: Teacher Wakoor, Student Wakoor, Administration Wakoor, Curriculum Wakoor, Sarpras Wakoor, Wakoor Mu'adalah, Kepegawaian
Wakoor and Kepesantrenan Wakoor. As well as MBI also conducts annual work meetings. All of these are aimed at monitoring and evaluation (monev) in the business process to achieve optimal, maximum results and also achieve success.

Likewise in terms of work commitment and sincerity, leaders provide examples or demonstrate the importance of responsibility in doing a job. Start with a sense of belonging to a job, because the MBI leader is someone who likes to nurture and provide direct guidance. From some of the explanations above, the teacher's performance at MBI AU Pacet Mojokerto has an active role in achieving the vision, mission, and goals of the madrasah. In accordance with the existing madrasa commitments, namely: "Believing, having faith, knowledge, discipline, responsibility, clean, polite, friendly, neat". The vision, mission and goals of the madrasah will be achieved because the teacher's performance is maximum and also has a forward orientation.

This research is strengthened by research conducted by Lathifah and Rustono, entitled "The Influence of Organizational Culture on Employee Performance at Madrasah Aliyah Negeri (MAN) Cimahi". The results of this study concluded that: (1) the organizational culture of MAN Cimahi is very good, (2) the performance of the employees of MAN 
Cimahi is very good, (3) the organizational culture has a significant effect on the performance of the employees of MAN Cimahi. In this study, the results show that there is an influence of organizational culture on the performance of teachers at SMP Negeri 2 Gamping Sleman Yogyakarta. Based on the results of this study and previous research, it is evident that organizational culture is very important to be given to employees in an organization, because with an organizational culture that is in accordance with the work that has been done, employees will work more optimally. With maximum performance, the vision and mission of the organization can indirectly be realized.

\section{Effect of Work Motivation on Teacher Performance:}

In accordance with the results of data analysis using SPSS version 25, the effect of work motivation on teacher performance is $44.7 \%$, and the research $t$ score is $2.181>\mathrm{t}$ table is 2.00247 . This shows the results in which the $\mathrm{X} 2$ variable (work motivation) has a significant effect on the $\mathrm{Y}$ variable (teacher performance).

Maslow's Need Herarchy Theory or A Theory of Human Motivation, which was put forward by Abraham Maslow in 1943 and stated that the needs and satisfaction of an individual consist of biological and psychological needs in the form of material and non-material. It is important for
Maslow's thinking that the needs that have been met provide motivation to work for someone. In this regard, work motivation has several indicators that researchers take and use from the theory of needs put forward by Abraham Maslow, namely: physiological needs, safety and security needs, social needs, reward needs, and selfactualization needs.

Work motivation in $\mathrm{MBI}$ is very influential on teacher performance. In terms of physiological needs, the leadership is very concerned about, especially in terms of the welfare of teachers. Apart from demanding obligations, there are rights and welfare of teachers which are also given or facilitated. Namely in the case of honorary (salaries), which in MBI there are 3 levels (grade) of teachers, namely: grade A, B and $\mathrm{C}$ which are given depending on the level of the teachers by having several provisions, namely by looking at how teachers work professionally during in this institution, and there are also other assessments that are determined by the length of time teaching at the institution, student assessments and also attention to discipline.

Apart from the honorarium (salary) according to grade, there are other benefits that are also provided, namely providing facilities called BMI (Baitul Maal wal Isti'arah). There are loan facilities without interest and collateral. Teachers are welcome to apply for loans, according to 
the criteria that have been made or agreed upon, namely the ability to pay as seen from the HR received every month. Because the BMI must be responsible for this. Funds obtained are from deductions from teacher salaries every month, deductions are also determined by the grade of the teachers. In addition to managing savings, BMI also includes pension funds and social funds. All teachers will receive a pension fund if they resign from the madrasah. Likewise with social funds, whether it is a disaster, serious illness, or even death experienced by the teachers' biological families, all will be covered using social funds. Of course, social needs are also very much considered by madrasas.

This research will also be strengthened by research conducted by Rahayu, entitled "The Effect of Motivation and Job Satisfaction on Teacher Performance at SMP Negeri 5 Magelang". The results of this study indicate that in this study there is an effect of motivation and job satisfaction on teacher performance at SMP Negeri 5 Magelang, either simultaneously or partially.

\section{The Influence of Organizational Culture and Work Motivation on Teacher Performance}

In accordance with the results of the analysis which shows that there is a simultaneous significant and also positive influence between organizational culture and work motivation on teacher performance at MBI AU Pacet Mojokerto, so that the results of the calculation are $96.8 \%$ and $\mathrm{F}$ research is $183.517>\mathrm{F}$ table 3.16. These results are based on calculations obtained using SPSS version 25.

Zameer stated that, in order for good performance to be achieved, Human Resources (HR) are required to have knowledge, skills, abilities, experience, work motivation, cultural values, self-discipline, and high work morale. So that the employee's performance is good which will have an impact on the company's performance which will also increase, and in the end all goals will be achieved.

Organizational culture and work motivation have a strong and strong influence on the performance of teachers in MBI. Because there is or embedded organizational culture that exists in individual teachers. So as to create good results that are given to madrasas and the achievement of the expected goals, and of course will continue to provide motivation or support for teachers in carrying out the tasks and responsibilities that have been given. Teachers who have understood the values of an organization will make this a personality in the organization itself. Existing human resources will be supported by systems, technology, and strategies. Each individual good performance will also lead to good organizational performance as well. 
Organizational culture and work motivation have a strong and strong influence on the performance of teachers in MBI. Because there is or embedded organizational culture that exists in individual teachers. So as to create good results that are given to madrasas and the achievement of the expected goals, and of course will continue to provide motivation or support for teachers in carrying out the tasks and responsibilities that have been given. Teachers who have understood the values of an organization will make this a personality in the organization itself. Existing human resources will be supported by systems, technology, and strategies. Each individual good performance will also lead to good organizational performance as well.

This research is also strengthened by Wuryantina (2015) entitled "The Influence of School Organizational Culture and Motivation with Teacher Performance in Public Elementary Schools of Gugus Adiarsa Karawang Barat". The results of this study are: (1) there is a positive relationship between school organizational culture and teacher performance. (2) there is a positive relationship between motivation and teacher performance, (3) there is a positive relationship between school organizational culture and motivation together with teacher performance.

\section{CONCLUSSION}

Based on the results of data analysis of the influence of organizational culture and work motivation on teacher performance at the Amanatul Ummah Pacet Mojokerto International Standard Madrasah (MBI), this chapter concludes:

There is an influence between organizational culture (X1) on teacher performance $(\mathrm{Y})$. This can be concluded from the calculation results using SPSS version 25. The significance level uses 0.05. So that the $\mathrm{t}$-research number is $2.655>\mathrm{t}$ table is 2.00247. The magnitude of the influence between the variable $\mathrm{X} 1$ on $\mathrm{Y}$ is $54.5 \%$.

There is an influence between work motivation (X2) on teacher performance $(Y)$. This can be concluded from the analysis results for a significance level of 0.05. So that the t-research number is $2.181>\mathrm{t}$ table is 2.00247 . The magnitude of the influence between the $\mathrm{X} 2$ variable on $\mathrm{Y}$ is $44.7 \%$.

The results of the analysis of the influence of organizational culture and work motivation on teacher performance have been carried out by researchers, which are obtained from the results of the respondents' answers through a questionnaire that has been distributed to 60 samples (respondents), calculations with the help of the SPSS application version 25. So that based on the test results the 
coefficient of determination (R2) obtained F research of 183.517> F table which is equal to 3.16. And it shows a significance level of $0.000<0.05$. So it can be concluded that there is a positive and significant influence between organizational culture (X1) and work motivation (X2) on teacher performance $(Y)$. The amount of influence between these variables is $96.8 \%$. Meanwhile, the magnitude of the influence of other variables outside the model is $3.2 \%$.

\section{REFERENCES}

Ab Halim Tamuri, Mohd Yusof Othman, Jawiah Dakir, Ahmad Munawar Ismail, \& Zakaria Stapa. (2013). Religious education and ethical attitude of Muslim adolescents in Malaysia. Multicultural Education \& Technology Journal, 7(4), 257-274. https://doi.org/10.1108/METJ-032013-0008

Abd Hamid, S. R., Syed Hassan, S., \& Ismail, N. A. (2012). Teaching Quality and Performance Among Experienced Teachers in Malaysia. Australian Journal of Teacher Education, $37(11)$.

https://doi.org/10.14221/ajte.2012 v37n11.2

Abdullah, M. (2019). School Culture to Serve Performance of Madrasah in Indonesia. QIJIS (Qudus International Journal of Islamic Studies), 7(1), 71. https://doi.org/10.21043/qijis.v7i1. 4809

Abdullah, M. L., \& Syahri, A. (2019). Model of Religious Culture Education and Humanity. Nadwa, 12(2), 331-344. https://doi.org/10.21580/nw.2018. 12.2.2756

Alam, N. A. R. (2018). Strengthening Leadership Culture (The Role of Kyai in Indonesian Pesantren). AtTa'dib, 13(1), undefined-undefined. https://doi.org/10.21111/attadib.v13i1.1986

Alkrdem, M. S., \& Alqahtani, A. S. (2016). Educational Management in the Light of Islamic Standards. Journal of Education, Society and Behavioural Science, 1-9. https://doi.org/10.9734/BJESBS/2 $016 / 22671$

Amaliah, I., Aspiranti, T., \& Purnamasari, P. (2015). The Impact of the Values of Islamic Religiosity to Islamic Job Satisfaction in Tasikmalaya West Java, Indonesia, Industrial Centre. Procedia - Social and Behavioral Sciences, 211 , 984-991. https://doi.org/10.1016/j.sbspro.2 015.11 .131

Baker, D., \& Reyes, P. B. (2020). Religious Educators are the Future. Religious Education, 115(1), 1-9. https://doi.org/10.1080/00344087. 2020.1706422 
Belcourt, M., \& McBey, K. J. (2013). Strategic buman resources planning (5th ed.). Nelson Education.

Berglund, J. (2019). State-Funded FaithBased Schooling for Muslims in the North. Religion \& Education, 1-24. https://doi.org/10.1080/15507394. 2019.1590943

Brandmiller, C., Dumont, H., \& Becker, M. (2020). Teacher Perceptions of Learning Motivation and Classroom Behavior: The Role of Student Characteristics. Contemporary Educational Psychology, 101893. https://doi.org/10.1016/j.cedpsych .2020 .101893

Chalim, S., Sujono, G., \& Usman, F. (2020).

Trend Analysis Based Educator Planning. Nazhruna: Jurnal Pendidikan Islam, 3(2), 273-284. https://doi.org/10.31538/nzh.v3i2. 683

Chen, C.-F., \& Chen, C.-T. (2014). The Effect of Higher Education Brand Images on Satisfaction and Lifetime Value from Students' Viewpoint. The Anthropologist, 17(1), 137-145. https://doi.org/10.1080/09720073. 2014.11891423

Chhapra, S. U., Naz, S., Usmani, M., \& Mohiuddin, A. (2018). Analysis of Students Perception about Teachers' Personality in the Academic Achievement.
TARBIYA: Journal of Education in Muslim Society, 5(1), 101-115. https://doi.org/10.15408/tjems.v5i 1.7098

Darma, P. S., \& Supriyanto, A. S. (2017). The effect of compensation on satisfaction and employee performance. Management and Economics Journal (MEC-J), 1(1).

Ekosusilo, M., \& Soepardjo, S. (2014). Faktor Dominan Yang Memengaruhi Motivasi Kerja, Kinerja, Dan Kepuasan Kerja Guru SMA. Jurnal Ilmu Pendidikan, 20(2).

Fajriana, A. W., \& Aliyah, M. A. (2019). Tantangan Guru dalam Meningkatan Mutu Pendidikan Agama Islam Di Era Melenial. Naz̧hruna: Jurnal Pendidikan Islam, 2(2), 246-265. https://doi.org/10.31538/nzh.v2i2. 324

Felicen, S. S., Rasa, L. C., Sumanga, J. E., \& Buted, D. R. (2014). Internship performance of tourism and hospitality students: Inputs to improve internship program. International Journal of Academic Research in Business and Social Sciences, $4(6), 42$.

Hagger, M. S., \& Chatzisarantis, N. L. D. (2012). Transferring motivation from educational to extramural contexts: A review of the trans- 
contextual model. European Journal of

Psychology of Education, 27(2), 195212.

https://doi.org/10.1007/s10212-

011-0082-5

Hallinger, P., \& Hammad, W. (2019). Knowledge production on educational leadership and management in Arab societies: A systematic review of research. Educational Management Administration \& Leadership, 47(1), 20-36. https://doi.org/10.1177/17411432 17717280

Hassi, A. (2012). Islamic perspectives on training and professional development. The Journal of Management Development, 31(10), 1035-1045.

https://doi.org/10.1108/02621711

211281816

Ishan, R. (2018). Pengaruh Budaya Organisasi dan Motivasi Terhadap Kinerja Guru Melalui Variabel Intervening Kepuasan Kerja SMP Negeri 2 Gamping Kabupaten Sleman.

Jones, W., \& Rao, C. N. R. (2008). Supramolecular Organization and Materials Design. Cambridge University Press.

Marquardt, M. J. (2011). Building the Learning Organization: Achieving Strategic Advantage through a Commitment to Learning. Quercus. https://books.google.co.id/books?i $\mathrm{d}=\mathrm{iSghPdu} 71 \mathrm{XUC}$

Mathis, R. L., \& Jackson, J. H. (2011). Human resource management: Essential perspectives. Cengage Learning.

Mesiono, M. (2019). The Influence of Job Satisfaction on the Performance of Madrasah Aliyah (Islamic Senior High School) Teachers. Tadris: Jurnal Keguruan Dan Ilmu Tarbiyah, 4(1), 107-116. https://doi.org/10.24042/tadris.v4i 1.4388

Muri, Y. (2017). Metode Penelitian Kuantitaif, Kualitatif, dan Penelitian Gabungan (4th ed.). Kencana Prenada Media Group.

Nadolny, L. (2011). Connecting future teachers with the teachers of today. In Educating Educators with Social Media (Vol. 1, pp. 173-188). Emerald Group Publishing Limited. https://doi.org/10.1108/S20449968(2011)0000001011

Ridwan, M. (2018). Konsep Tarbiyah, Ta'lim Dan Ta'dib Dalam AlQur'an. Nąhruna: Jurnal Pendidikan Islam, $\quad$ 1(1), 35-57. https://doi.org/10.31538/nzh.v1i1. 41

Siahaan, A., Rafida, T., \& Batubara, K. (2020). Influence of Madrasah Head Leadership, Motivation and Madrasah Culture on Teacher 
Nidhomul Haq, Vol 6, Issue 1, 2021

Performance in Madrasah Aliyah

Model 2 Medan. Budapest

International Research and Critics

Institute (BIRCI-Joumal): Humanities

and Social Sciences, 3(3), 2174-2182.

https://doi.org/10.33258/birci.v3i3

.1150

Sugiyono. (2014). Metode penelitian Kuantitatif Kualitatif dan R\&D (Ed. 14).

Alfabeta.

Warti'ah, W. (2020). The Implementation of Madrasa Culture in Building Students' Character. Nað̧runa: Jurnal Pendidikan Islam, 3(2), 247259.

https://doi.org/10.31538/nzh.v3i2. 583

Young, F. Y. F. (2009). The Impact of Human Resource Management on Small and Medium Enterprise Success in Hong Kong. The Open Area Studies Journal, 2(1). https://benthamopen.com/ABSTR ACT/TOARSJ-2-31 